\title{
The effect of thyme (Thymus daenensis) supplement on growth and hygienic parameters of broilers meat
}

\author{
M. Gholami-Ahangaran ${ }^{1 *}$, N. Peimani ${ }^{2}$ and A. Ahmadi-Dastgerdi ${ }^{3}$ \\ ${ }^{1}$ Department of Poultry Diseases, Veterinary Medicine Faculty, Shahrekord Branch, Islamic Azad University, Shahrekord, Iran \\ ${ }^{2}$ Undergraduate of Veterinary Medicine Faculty, Shahrekord Branch, Islamic Azad University, Shahrekord, Iran \\ ${ }^{3}$ Department of Food Science and Technology, Agriculture Faculty, Ardestan Branch, Islamic Azad University, Ardestan, Iran \\ "email:mgholamia1388@yahoo.com
}

(Received May 16, 2018; Accepted July 15, 2018)

\begin{abstract}
The antibacterial effect of Thyme species was relatively approved but the effect of this plant on bacterial population of intestine in chickens and consequently on bacterial load of chicken meat following administration of thyme was not investigated. For evaluation of thyme effect on growth indices, microbial contamination of meat and microbial population of cecal content, 180 broiler chicks were divided into 4 equal groups with 3 replicates and were reared until 42 days. Chickens in different groups were treated with different doses of thyme $(0,0.25,0.50$ and 1 percent $)$ in diets. The weight gain, feed consumption and feed conversion rate were calculated weekly. In the end of 42 days old, all chickens were slaughtered. The population of Escherichia coli per gram of cecal contents and contamination of meat with Escherichia coli were assayed. The data showed that supplement of 0.5 and 1 percent of thyme to diet elevated weight gain and decreased feed conversion rate. Furthermore, addition of 0.5 and 1 percent of thyme to diet can decrease microbial population of cecal content and meat. In conclusion, the addition of thyme to diet may improve growth rate and hygienic parameters in chicken meat.
\end{abstract}

Keywords: Thyme, Broiler chicken, Performance, Escherichia coli, Meat

Available online at http://www.vetmedmosul.com

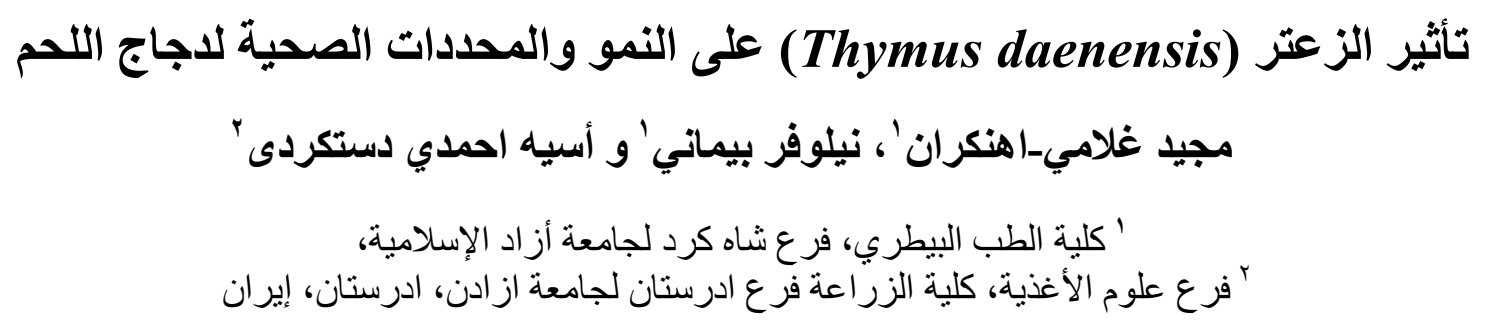

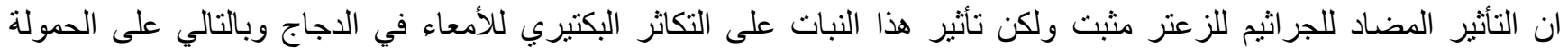

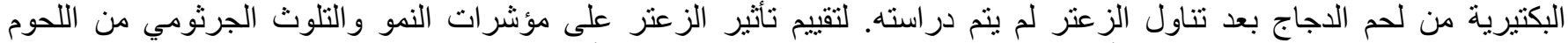

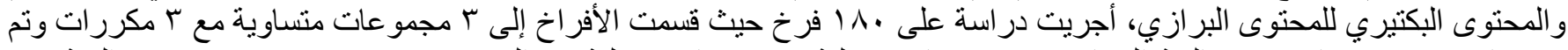

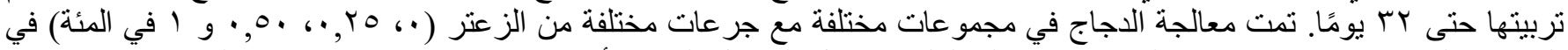

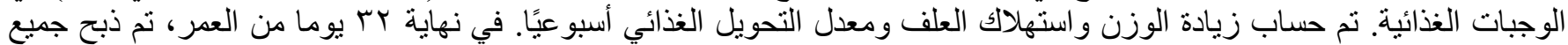

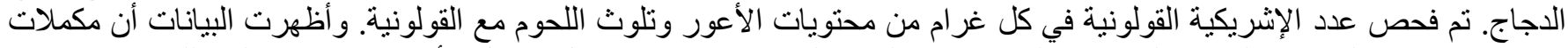

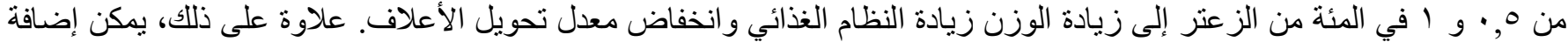

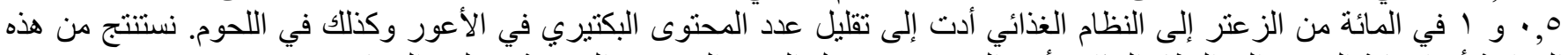

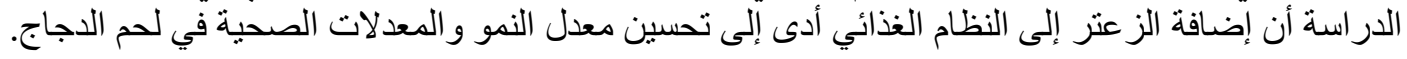




\section{Introduction}

Escherichia coli (E. coli) is an important bacterium in the health of the birds. The bacterium is the normal flora of the digestive tract of all birds and warm-blooded animals that typically drawn through feces. There is around one million E. coli in one gram of feces of birds but, about 10 to $15 \%$ of these bacteria are pathogens (1). In high populations of growing chickens the pathogenic bacteria enter the respiratory and gastrointestinal tract because of high activity of chickens, low humidity of litter and poor ventilation. Therefore, these conditions favored the entering of bacteria to digestive tract and colonizing the intestines (1). Unfortunately, contamination of meat with digestive material that contains pathogenic bacteria such as E. coli is inevitable during evisceration. Consequently, detection of $E$. coli from carcass assumed as indicator of recent fecal contamination (2).

Foodborne illness is an important public health problem in most countries. There are some researches that represent certain food regimes which can increase food safety and reduce microbial load of the gastrointestinal tract of birds $(3,4)$. Using of these specific regimes adjacent to the health care can directly control microbial disease in the birds and indirectly in humans $(3,4)$. Using antibiotics as food additives in poultry diets can lead to antibiotic resistance and high residue level in poultry products such as meat and egg (5). Using of medicinal plants in poultry food with fewer side effects and no problems associated with residue in poultry product such as meat and egg can be a good option. Due to the increasing demand on the use of organic chickens, the use of medicinal plants in poultry diets has become more popular worldwide as an alternative to antibiotics. Thus, in the current study the effect of different doses of Thymus daenensis supplement in broiler diet on growth performance and microbial load of meat were evaluated.

\section{Materials and methods}

\section{Study design}

In this study, 180 broiler chicks (ROSS strain) were randomly divided into four equal groups with three replicates in 12 separate pens. So, per pen 15 broilers were reared until 42 days of age. All chickens in different groups were received feed and water freely (ad libitum) and same growing conditions e.g. ventilation, humidity, lighting and temperature were applied. Diets for all groups prepared based on corn-soy. Diets were balanced according to the NRC in the whole growing period (6). All chickens were received thymus daenensis powder from 5 days old until slaughter, based on following pattern in diet: The first group, as the control group not received powdered thyme. The second, third and fourth groups received powdered thyme to the $0.25,0.5$ and one percent of the diet, respectively. All chickens were vaccinated against infectious bronchitis, Newcastle and Gumboro disease according to routine vaccination programs. The weight gain, feed intake and feed conversion ratio in 21 st and $42 \mathrm{nd}$ days of age were calculated and were compared across groups.

At 42nd day of age, all chickens were slaughtered and cecal contents were collected from each bird individually in sterile test tubes. In addition, a piece of breast muscle of each bird was collected in a sterile test tube. Samples were stored in $4-8{ }^{\circ} \mathrm{C}$ until experiment. Muscle samples were assessed for contamination with $E$. coli and cecal content samples for $E$. coli colony count per gram $(\mathrm{CFU} / \mathrm{g})$ were tested bacteriology after 2 days.

\section{E. coli colony count}

Nine $\mathrm{ml}$ of peptone water was added to one $\mathrm{g}$ of the cecal content or muscle sample and were stirred for 3 to 5 minutes. Tenfold serial dilution for each sample was made with sterile $0.1 \%$ peptone water, until they were diluted to 10-7 to enumerate E. coli. For each of the dilutions two sterile empty plates were considered and from each dilution, one $\mathrm{ml}$ of diluted solution was added to each plate. Then, $25 \mathrm{ml}$ of molten MacConkey culture medium was added. Mixing was done by moving the plates in a circular motion. Plates were left on a table and allowed to solidify. The plates were incubated at $37^{\circ} \mathrm{C}$ for $48 \mathrm{hrs}$ (7). To confirm the lactose-positive colonies (pink) as E. coli, the five suspected colonies were cultured linearly on EMB medium and incubated for $24 \mathrm{~h}$ at $37^{\circ} \mathrm{C}$. Lactose positive colony created metallic green luster on EMB medium identified primarily as Escherichia coli. Then, the differential IMVIC tests were performed on the colonies. If indole production, methyl red (MR), Voges-Proskauer (VP) tests and citrate utilization test were positive, positive, negative, negative, the suspected colonies identified as $E$. coli.

E. coli count was determined according to US Bacteriological Analytical Manual (8). After $48 \mathrm{hrs}$ of incubation, colonies on MacConkey were counted visually. The number of counted colonies was multiplied by the level of dilution. Finally, the total number of $E$. coli per gram of sample was obtained.

Bacterial colonies were expressed as $\log 10$ colony forming units per gram (CFU/g) (9). Preparation of decimal dilutions, identification of $E$. coli and enumerations of $E$. coli was done following the method described in Feng et al. (8).

\section{Statistical Analysis}

All quantitative data such as weight gain, feed intake, feed conversion ratio, the number of $E$. coli colonies per gram of cecal content and muscle samples were analyzed 
with SPSS software and statistics program of analysis of variance (One away ANOVA).

If there is a statistical difference between the mean of data in different groups, the difference was expressed by Tukey test. The significant difference level was considered less than 0.05 . The percentage of E. coli infection was compared between groups by Chi-Square.

\section{Result}

\section{Growth and performance indices}

The Comparison of growth and performance indices in different groups showed that the mean of body weight in one day old was similar in all groups. At the end of the first week, weight gain, feed intake and feed conversion ratio were similar in all groups and no significant difference was observed between groups (Table 1).

Comparative data in the third week showed that there was the highest weight gain in chickens receiving $1 \%$ thyme but had no significant differences with the chickens receiving 0.5 and 0.25 percent. At the end of the third week, the cumulative weight gain in control chickens had no significant difference with the chickens receiving 0.25 percent thyme and it was significantly lower than the other groups. Comparison of feed intake in the third week of growing period showed there was no significant difference between treatment groups. In the end of third week, the feed conversion ratio in the chicken received $1 \%$ thyme was significantly lower than the control group $(\mathrm{P}<0.05)$. In the third week, there was no significant difference in feed conversion ratio in chickens received $1,0.5$ and 0.25 percent thyme (Table 1).

At the end of the sixth week of the growing period, the highest weight gain was observed in the chickens received 0.5 percent of thyme but had no significant difference with other chickens received one and 0.25 percent of thyme, which were significantly higher than the control group $(\mathrm{P}<$ 0.05). Comparison of cumulative feed intake at the end of the sixth week of the growing period showed no significant difference between different groups, but the feed conversion at the end of the sixth week of growing period in chickens fed 0.5 and one percent thyme were significantly lower than control chickens and chickens received 0.25 percent of thyme. However, there was no significant difference in feed conversion rate in control chickens and chickens received 0.25 percent thyme. Also, there was no significant difference in feed conversion rate in chickens received 0.5 and 1 percent thyme (Table 1).

Table 1: Growing indices in different studied groups

\begin{tabular}{lcccc}
\hline Groups & $\begin{array}{c}\text { Control broilers (not } \\
\text { received thyme) }\end{array}$ & $\begin{array}{c}\text { Broilers received } \\
0.25 \% \text { thyme }\end{array}$ & $\begin{array}{c}\text { Broilers received } \\
0.5 \% \text { thyme }\end{array}$ & $\begin{array}{c}\text { Broilers received } \\
1 \% \text { thyme }\end{array}$ \\
\hline BW in one day old $(\mathrm{g})$ & $48.1 \pm 2.09$ & $47.3 \pm 2.53$ & $48.0 \pm 2.51$ & $47.8 \pm 2.03$ \\
WG in first week $(\mathrm{g})$ & $106.1 \pm 3.45$ & $106.2 \pm 5.73$ & $111.5 \pm 3.80$ & $110.3 \pm 4.13$ \\
FI in first week $(\mathrm{g})$ & $93.2 \pm 6.92$ & $91.4 \pm 6.30$ & $89.4 \pm 5.02$ & $87.7 \pm 4.73$ \\
FCR in first week $(\mathrm{g} / \mathrm{g})$ & $0.87 \pm 0.02$ & $0.86 \pm 0.06$ & $0.80 \pm 0.05$ & $0.79 \pm 0.04$ \\
Cumulative WG in third week $(\mathrm{g})$ & $706.9 \pm 26.4^{\mathrm{b}}$ & $730.3 \pm 24.2^{\mathrm{ab}}$ & $734.9 \pm 18.5^{\mathrm{a}}$ & $749.8 \pm 25.7^{\mathrm{a}}$ \\
Cumulative FI in third week $(\mathrm{g})$ & $865 \pm 18.1$ & $860 \pm 17.0$ & $840 \pm 25.3$ & $835 \pm 25.9$ \\
Cumulative FCR in third week $(\mathrm{g} / \mathrm{g})$ & $1.23 \pm 0.09^{\mathrm{a}}$ & $1.18 \pm 0.02^{\mathrm{ab}}$ & $1.13 \pm 0.05^{\mathrm{ab}}$ & $1.09 \pm 0.05^{\mathrm{b}}$ \\
Cumulative WG in sixth week $(\mathrm{g})$ & $2124 \pm 140^{\mathrm{b}}$ & $2160 \pm 179^{\mathrm{ab}}$ & $2328 \pm 182^{\mathrm{a}}$ & $2276 \pm 143^{\mathrm{ab}}$ \\
Cumulative FI in sixth week $(\mathrm{g})$ & $3842 \pm 341$ & $3867 \pm 265$ & $3698 \pm 175$ & $3675 \pm 170$ \\
Cumulative FCR in sixth week $(\mathrm{g} / \mathrm{g})$ & $1.81 \pm 0.09^{\mathrm{a}}$ & $1.79 \pm 0.21^{\mathrm{a}}$ & $1.59 \pm 0.16^{\mathrm{b}}$ & $1.61 \pm 0.14^{\mathrm{b}}$ \\
\hline
\end{tabular}

BW: Body Weight, FI: Feed Intake, FCR: Feed conversion rate, Data presented as mean \pm standard deviation.

$\mathrm{A}, \mathrm{b}, \mathrm{c}$ : different characters represents significant differences between groups in each row $(\mathrm{P}<0.05)$.

\section{Percentage of meat contamination}

The comparison of percentage of meat contamination with $E$. coli in different groups was studied. The highest meat contamination was observed in chickens received $0.25 \%$ thyme and control chickens and least meat contamination was observed in chickens consumed one and 0.5 percent of thyme. There was significant difference in the highest and the least percentage of meat contamination $(\mathrm{P}<0.05)$ (Table 2).

\section{Number of $E$. coli colonies per gram of cecal content}

Comparison of $E$. coli population in the cecal content of chickens receiving various doses of thyme showed the supplement of 0.5 and one percent of thyme in chicken diet can significantly reduce populations of $E$. coli in the cecum $(\mathrm{P}<0.05)$. However, the population of $E$. coli in the cecal contents of chicks receiving 0.25 percent thyme compared to the control group and also the chickens receiving 0.5 and one percent of thyme had no significant difference (Table 2). 
Table 2: Percentage of meat contamination and E. coli count in cecal content

\begin{tabular}{lcccc}
\hline Groups & $\begin{array}{c}\text { Control broilers } \\
\text { (not received } \\
\text { thyme) }\end{array}$ & $\begin{array}{c}\text { Broilers } \\
\text { received } 0.25 \% \\
\text { thyme }\end{array}$ & $\begin{array}{c}\text { Broilers } \\
\text { received } 0.5 \% \\
\text { thyme }\end{array}$ & $\begin{array}{c}\text { Broilers } \\
\text { received 1\% } \\
\text { thyme }\end{array}$ \\
\hline Meat contamination with $E$. coli $(\%)$ & $53 \pm 14.54^{\mathrm{a}}$ & $47 \pm 11.26^{\mathrm{a}}$ & $35 \pm 7.28^{\mathrm{b}}$ & $24 \pm 9.22^{\mathrm{b}}$ \\
E. coli colony count in cecal content $\left(\log _{10} \mathrm{cfu} / \mathrm{g}\right)$ & $7.91 \pm 2.35^{\mathrm{a}}$ & $6.93 \pm 1.85^{\mathrm{ab}}$ & $4.75 \pm 1.76^{\mathrm{b}}$ & $5.16 \pm 1.65^{\mathrm{b}}$ \\
\hline
\end{tabular}

Data presented as mean \pm standard deviation.

$\mathrm{A}, \mathrm{b}, \mathrm{c}$ : different characters represents significant differences between groups in each row $(\mathrm{P}<0.05)$.

\section{Discussion}

Poultry meat is a rich source of protein, iron, phosphorus and vitamin D. Lower fat of this protein source compared to other animal proteins causes increased consumption of such protein $(3,6)$. One of the major health challenges of the products is meat and meat products contamination with pathogenic micro-organisms (2). Approaches that reduce microbial contamination of meat and by products can increase the quality and shelf life of meat having important concerns on public health (4). Another impact of the consumers of meat products is the great use of chemicals in poultry growing as well as the antibiotic residual and transmission of genes related to antibiotic resistance in meat products (5). So, there is more enthusiasm for the use of natural ingredients in poultry feed. Medicinal plants may be a good alternative to antibiotics in poultry diets. Iran due to particular climatic conditions is one of the richest sources of medicinal plants (10). Thyme is a genus of the spearmint family that their 14 species grow in different regions of the Iran especially Dena Mountains $(10,11,12)$. The main compounds are thymol and carvacrol that have antimicrobial effect of thyme are attributed to these two compounds $(13,14)$. According to available information, thyme antibacterial effect was evaluated in different infections in vitro (15-17) and in clinical trials $(18,19)$ in different species of animals (18-21) and sometimes in humans $(22,23)$. These studies indicate that thyme has effective antibacterial effect on a variety of gram-positive and gram-negative bacteria, including Streptococcus agalactiae (15), Streptococcus pyogenes (16), Staphylococcus aureus $(15,24)$ of Salmonella typhimurium (23), Listeria monocytogenes (24), Pseudomonass aerogenusa $(16,24)$ and Escherichia coli $(15,16,24)$. Antimicrobial effect of thyme on Escherichia coli isolated from bovine mastitis (15), hemorrhagic enteritis (22) and colisepticemia (24) are proven. Some reports are available for antimicrobial effect of thyme in poultry $(25,17)$. For example, Kivanc and Akguel (25) showed that thyme can reduce oocysts of coccidia and clostridial populations in broiler chickens. In addition, Akhondzadeh et al. (17) stated that different percentages of thyme essential oils have negative effects on the growth of Salmonella typhimurium. However, although the antibacterial activity of thyme has been demonstrated in many destinations, the purpose of the recent study is to evaluate the use of thyme in poultry diet as a reducing agent of $E$. coli population in gastrointestinal system as well as the possible improvement of growth indices and meat contamination reduction. Concerning thyme effects on the gastrointestinal microflora, few reports are available $(21,26)$. Cross et al. $(26)$ showed that thymol as essential oil extracted from thyme can significantly reduce the total number of coliform bacteria in the gastrointestinal tract. Also, Tschirch (21) stated that carvacrol as one component of thyme essential oil had a positive effect on the growth and proliferation of intestinal lactobacillus species.

In the recent study, three doses of $0.25,0.5$ and one percentage of Thyme daenensis from 5 days until 42nd days of age were used in poultry diets. Results showed that adding of the thyme to the diet had no effect on feed intake up to the end of 42 days old, while doses of 0.5 and one percent thyme significantly increased weight gain and feed conversion in 21 and 42 days old compared to the control group. In addition, the percentage of meat contamination with $E$. coli and their populations in the cecum in chickens fed 0.5 and one percentage of the thyme were significantly lower than chickens fed control diet. The pattern of reduction in population of $E$. coli in the cecum and percentage of meat contamination with $E$. coli was the same and in all three doses of thyme $(0.25,0.5$, one percent) in 21- and 42-days old cause improved in growth and performance, and meat hygienic quality. So, it seemed that the change in population of the microflora of gastrointestinal tract following administration of 0.5 or one percent of thyme in diet decreased meat contamination with intestinal content. Earlier, it had been demonstrated that thymol, as the main compound extracted from thyme, involved as a hydrophobic component in function of cell membrane in microorganisms $(12,27)$. Thymol can cause a change in membrane permeability to $\mathrm{K}^{+}$and $\mathrm{H}^{+}$cations. The increase in cell permeability leads to exclusion and leakage of ions and other cell contents and eventually causes bacterial cell death $(12,27)$.

In the recent study, administration of 0.5 and one percent of thyme in chicken diet, with no effect on feed intake, could cause increasing in weight gain and improvement of feed conversion. These findings indicate 
that the addition of one percent of thyme to diet do not reduce food intake. Some reports suggest that the effective ingredients in medicinal plants play role in performance and digestive enzymes secretion. On the other hand, flavonoids in medicinal plants effect on function of biochemistry and physiology of the digestive system (2426). Such effect is due to improvement in the enzyme activity and totally digestion and absorption, indirect increase in weight gain and feed efficiency. However, whether the improved performance of gastrointestinal tract resulting from thyme consumption was associated with decreasing intestinal bacterial populations or no, further investigation is needed.

In the recent study, the supplement of 0.25 percent of thyme to the diet of broiler chickens had no effect on feed efficiency but Bolukbasi et al. (18) showed that adding of 0.1 percent of thyme to the diet of laying hens improved performance and egg production. In addition, Sarica et al. (20) suggested that the addition of 0.1 percent thyme reduced intestinal $E$. coli number significantly compared to control group. This difference may be due to the wide variety of different species of thyme around the world so that this diversity makes a difference in the amount of effective ingredient of used thyme in the various studies.

\section{Conclusions}

This study showed that the supplement of 0.5 and one percent thyme in poultry diet reduced $E$. coli populations in the gastrointestinal tract and the percentage of contamination of broiler meat, and improved weight gain and feed conversion ratio without affecting on feed intake. However, the addition of $0.25 \%$ of thyme to the broiler diet had no effect.

\section{Acknowledgement}

This work was supported by Islamic Azad University, Shahrekord Branch. We appreciate the deputy of research in IAU, Shahrekord branch for assistance.

\section{Ethics approval}

All experimental procedures involving animals were conducted in accordance with the Animal Experimental Guidelines provided by the Animal Care and Use Committee of Veterinary Medicine Faculty, Shahrekord Branch, IAU.

\section{References}

1. Nolan LK, Barnes HJ, Vaillancourt JP, Abdul-Aziz T, Logue CM. Colibacillosis. In: Swayne DE, Glisson JR, McDougald LR,
Nolan LK, Suarez DL, Nair VL, editors. Disease of Poultry. $13^{\text {th }}$ ed. Massachusetts: Wiley-Blackwell; 2013. p. 751-807.

2. Jime'nez SM, Tiburzi MC, Salsi MS, Pirovani ME, Moguilevsky MA. The role of visible fecal material as a vehicle for generic Escherichia coli, coliform, and other enterobacteria contaminating poultry meats during slaughtering. J Appl Mic. 2003;95:451-456.

3. Al-Nasser AY, Al-Zenki SF, Al-Saffar AE, Abdullah FK, Al-Bahouh ME, Mashaly M. Zeolite as a Feed Additive to Reduce Salmonella and Improve Production Performance in Broilers. Int J Poult Sci. 2011;10:448-454.

4. Johannsen SA, Griffith RW, Wesley IV, Scanes CG. Salmonella enterica serovar typhimurium colonization of the crop in the domestic turkey: Influence of probiotic and prebiotic treatment (L. acidophilus and lactose). Avi Dis. 2004:48:279-286.

5. Izadi H, Arshami J, Golian A, A Raji A. Effects of chicory root powder on growth performance and histomorphometry of jejunum in broiler chicks. Vet Res Forum. 2013;4:169-174.

6. National Research Council (NRC). Nutrient Requirements of Poultry. $9^{\text {th }}$ ed. Washington DC: National Academy Press; 1994.

7. Quinn, PJ, Markey Bk, Carter ME, Donnelly WJC, Leonard FC, Maguire D. Veterinary Microbiology and Microbial Diseases. $1^{\text {st }}$ ed. Massachusetts: Blackwell; 2002.

8. Feng P, Weagant S, Grant M. Enumeration of Escherichia coli and the Coliform Bacteria (Bacteriological analytical manual). 8th ed. Washington DC: US FDA centre for food safety and applied nutrition publishing; 2002.

9. Panitee Tippayatum P, Chonhenchob V. Antibacterial activity of thymol, eugenol and nisin against some food spoilage bacteria. Kasetstart J. 2007;41:319-23.

10. Bahmani M, Saki K, Rafieian-Kopaei M. Medicinal Plants of Thyme land in Iran. Saarbrücken: Lambert Academic Publishing; 2015.

11. Akbarinia, A. and Mirza, M. Identification of essential oil components of Thymus daenesis celak, in field condition in Qazvin. J Qazvin UniMed Sci. 2008;12:58-62.

12. Noori N, Rokni N, Akhondzade A, Misaghi A, Toorian F. The antimicrobial effect of Zataria multiflora against E.coli O157: $\mathrm{H7}$ in minced beef during refrigerated storage. J Health Food. 2011;1:1-8.

13. Kunle O, Okogun J, Egamana E, Emojevwe E, Shok M. Antimicrobial activity of various extracts and carvacrol from Lippia multiflora leaf extract. Phytomed. 2003;10:59-61.

14. Swanson KMJ, Petran RL, Hanlin JH. Culture methods for enumeration of microorganisms. In: Downes FP, Ito K, editors. Compendium of methods for the microbiological examination of foods. 4th ed. Washington DC: American Public Health Association (APHA); 2001. p. 53-62.

15. Zahraei-Salehi T, Vojgani M, Bayat M, Torshizi H, Akhondzadeh A. Determination of minimum inhibitory concentration (MIC) of extract of Zataria,multiflora, against the clinical isolates of Streptococcus agalactiae Staphylococcus, aureus and E.coli. J Vet Res Univ Tehran. 2005;60:107-110.

16. Mohammapour G, Sattarimajd T, Mehrabian S, Hosseinzadeh A. Antibacterial and antifungal activity of three thymus species essential oils and two echotype of Ziziphora tenuior and Satureja bachtiarica. Sci J Islam Azad Univ. 2010;1:111-117.

17. Akhondzadeh A, Razavilou V, Abbasifar A. The effect of shirazi thyme on probably growth salmonella typhi in BHI mediom. J Med Plant. 2004;9:84-92.

18. Bolukbasi SC, Erhan MK. Effect of dietary thyme (Thymus vulgaris) on laying hen performance and Ecoli concentration in feces. Int J Nat Engin Sci. 2007;1:55-58.

19. Rahimi S, Teymouri Zadeh Z, Karimi Torshizi MA, Omidbaigi R, Rokni H. Effect of the three herbal extracts on growth performance, immune system, blood factors and intestinal selected bacterial population in broiler chickens. J Agr SciTech. 2011;13:527-539.

20. Sarica S, Ciftci A, Demir E, Kilinc K, Yildirim Y. Use of an antibiotic growth promoter and two herbal natural feed additives with and 
without exogenous enzymes in wheat-based broiler diets. South Afr J Anim Sci. 2005;23:61-72.

21. Tschirch $\mathrm{H}$. The use of natural plant extracts as production enhancers in modern animal rearing practices. Zeszyly Naukowe Akademici Rolniczej Wroclaw, Zootechnik. 2000; XXV (376): 25-39 (In Polish).

22. Goodarzi M, Sattari M, Najjar S, Goodarzi G, Bigdeli M. The effect of thyme on enterohaemorrhagic Escherichia coli. Lorestan Med J. 2006;8:63-68.

23. Moosavy MH, Basti AA, Misaghi A, Jabari-khamaneh H. Effects of Zataria multiflora on the growth of Salmonella typhimurium in a commercial barley soup. J Med Plants. 2009;2:109-111.

24. Karman S, Digrak M, Ravid U, Ilcim A. Effect of antibacterial and antifungal activity of essential oils of thymus revolutus Clelak from Turkey. J Ethnopharm. 2001;76:183-186.
25. Kivanc M, Akguel A. Antimicrobial activities of essential oils from Turkish spices and citrus. Flavoar Fragnance J. 1986;1:175-179.

26. Cross DE, Hillman K, Fenlon D, Deans SG, McDevitt RM, Acamovic T. Antibacterial properties of phytochemicals in aromatic plants in poultry diets. In: Acamovic T, Stewart S, Phennycott TW, editors. Poisonous plants and related toxins. Wallingford: $\mathrm{CAB}$ International; 2004.

27. Ultee A, Bennik HJ, Moezelaar R. The phenolic hydroxyl group of carvacrol is essential for action against the food-borne pathogen, Bacillus cereus. Appl Environ Mic. 2002;3:1561-1568. 